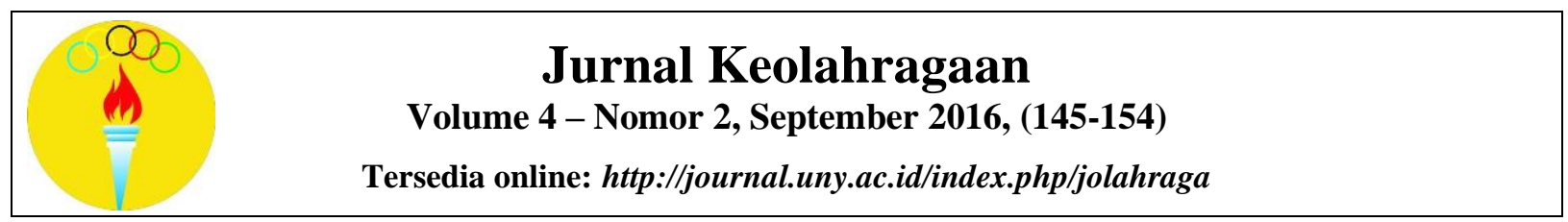

\title{
PENYUSUNAN TES FISIK ATLET PENCAK SILAT DEWASA KATEGORI TANDING
}

\author{
Cahniyo Wijaya Kuswanto \\ Institut Agama Islam Negeri Raden Intan Lampung. Jalan Letnan Kolonel H. Endro Suratmin, \\ Sukarame, Lampung 35131, Indonesia \\ Korespondensi Penulis. Email: cahyaniyowijayakuswanto@gmail.com, Telp: (+62721) 780887
}

Received: 27 October 2015; Revised: 27 October 2016; Accepted: 31 October 2016

\begin{abstract}
Abstrak
Penelitian ini bertujuan untuk menghasilkan sebuah pedoman tes fisik atlet pencak silat dewasa kategori tanding yang valid dan reliabel yang dapat digunakan untuk mengukur kondisi fisik atlet pencak silat dewasa kategori tanding. Jenis penelitian ini menggunakan metode penelitian dan pengembangan (Research and Development). Teknik Analisis data menggunakan penyusunan skor baku dengan rerata dan simpangan baku skor $\mathrm{T}$ yang digolongkan menjadi lima norma berdasar pada distribusi gejala normal, yaitu sangat baik, baik, sedang, kurang, sangat kurang. Data yang diperoleh tiap-tiap jenis tes merupakan data kasar dari hasil tiap tes yang di capai atlet. Selanjutnya hasil data kasar tersebut diubah dengan rumus $\mathrm{T}$ skor. Hasil penelitian ini diperoleh 9 (Sembilan) jenis tes fisik atlet pencak silat dewasa kategori tanding, antara lain: (1) Fleksibilitas (Side Splite), (2) Kecepatan (Sprint 40 Meter), (3) Power Lengan (Push Up 30 Detik), (4) Kekuatan Perut (Sit Up), (5) Kekuatan Punggung (Back Up), (6) Power Tungkai (Standing Triple Jump), (7) Kelincahan (Shuttle Run), (8) Daya tahan anaerobik (Sprint 300 meter), dan (9) Daya tahan aerobik (Bleep Tes). Tes ini dinyatakan valid dan menunjukkan koefisien reliabilitas putra dan putri $>0,5$.
\end{abstract}

Kata Kunci: tes pengukuran, pencak silat, kondisi fisik.

\section{THE CONSTRUCTION OF A PHYSICAL TEST OF ADULT FIGHTING CATEGORY PENCAK SILAT ATHLETE}

\begin{abstract}
This research was aimed to produce a valid and reliable guide book for a physical test for adult pencak silat athlete in fighting category. This guide book was supposed to measure the physical condition of adult pencak silat athlete at the fighting category. This research was using research and development method. The data analysis techniques used in this research were the construction of standard score by the mean and standard deviation of $T$ score. The $T$ score was classified into five norms based on normal indication distribution, namely very good, good, moderate, poor, and very poor. The data taken from each test was the raw data from the result of each test achieved by the athletes. Then, that result was changed into T-score. This research reveals nine types of physical test for adult pencak silat athlete at the fighting category. They are: (1) Flexibility (Side Splite), (2) Speed (Sprint 40 meters), (3) Arm Power (30 seconds Push Up), (4) Abdominal Strength (Sit Up), (5) Back Strength (Back Up), (6) Leg Power (Standing Triple Jump), (7) Agility (Shuttle Run), (8) Anaerobic Endurance (300 meters Sprint), and (9) Aerobic Endurance (Bleep Test). This test is valid and indicates reliability coefficient of male and female $>0.5$.
\end{abstract}

Keywords: measurement test, pencak silat, physical condition.

How to Cite: Kuswanto, C. (2016). Penyusunan tes fisik atlet pencak silat dewasa kategori tanding. Jurnal Keolahragaan, 4(2), 145-154. doi:http://dx.doi.org/10.21831/jk.v4i2.6423

Permalink/DOI: http://dx.doi.org/10.21831/jk.v4i2.6423 


\section{Jurnal Keolahragaan 4 (2), September 2016 - 146}

Cahniyo Wijaya Kuswanto

\section{PENDAHULUAN}

Pada awalnya prestasi pencak silat Indonesia merupakan acuan bagi negara-negara Asia Tenggara bahkan dunia, tetapi saat ini prestasi Indonesia di bidang pencak silat mengalami penurunan. Sebagai indikasi, adalah kegagalan Indonesia menjadi juara umum satu di tingkat Sea Games bulan Juni tahun 2015 dengan perolehan medali 3 emas 2 perak 5 perunggu. Padahal dalam event tersebut pencak silat merupakan ladang medali bagi Indonesia. Hal tersebut tentunya menjadi tantangan bagi bangsa Indonesia untuk kembali meningkatkan prestasi pencak silat, khususnya di tingkat Asia Tenggara dan di dunia pada umumnya.

Tujuan latihan salah satunya menyiapkan tubuh dengan baik sehingga saat pesilat mengikuti pertandingan sudah memiliki kondisi fisik yang baik. Pemilihan latihan fisik harus diprogram dengan baik kemudian diberikan kepada atlet supaya atlet secara memiliki kemampuan fisik yang baik. Setelah kondisi fisik terbentuk, maka akan mempermudah pelatih untuk membentuk program latihan selanjutnya yang berkaitan dengan teknik, taktik, dan mental. Pelatih yang profesional akan mengembangkan kondisi fisik pesilat disertai dengan perencanaan dan program latihan secara sistematis. Program latihan diantaranya bertujuan meningkatkan kualitas fisik pesilat agar benarbenar siap untuk bertanding. Menurut Iswana \& Siswantaya (2013, p.27) Prinsip dasar olahraga pencak silat adalah membela diri yang di dalamnya terdapat nilai menyerang dan bertahan.

Berdasarkan pengamatan penulis di lapangan, komponen kondisi fisik yang dibutuhkan pencak silat kategori tanding meliputi: (1) daya tahan, (2) kekuatan, (3) kecepatan, (4) fleksibilitas, (5) koordinasi, (6) kelincahan, dan (7) power.

Beberapa variasi jawaban yang diberikan pelatih di atas menunjukan bahwa pelatih belum mempunyai dan mengetahui standar tes dan penilaian yang harus diberikan untuk pesilat kategori tanding. Seharusnya cara memberikan bentuk tes fisik harus tersusun dengan baik agar saat menentukan standar atlet tersebut dikatakan sebagai atlet yang sangat baik, baik, kurang baik, memiliki panduan yang benar. Jenis dan item tes harus disesuaikan dengan karekteristik pencak silat. Karena olahraga pencak silat untuk dewasa belum memiliki standar tes kemampuan kondisi fisik yang dijadikan sebagai standar norma atau acuan kemampuan fisik, untuk itu penulis tertarik menyusun tes fisik atlet pencak silat kategori tanding. Dengan mengetahui standar kondisi fisik dan urutan tes fisik pesilat kategori tanding yang benar, nantinya diharapkan memberikan kemajuan fisik yang baik sebelum pesilat tersebut mengikuti pertandingan dan meraih hasil yang optimal.

\section{METODE}

Penelitian ini menggunakan metode penelitian dan pengembangan (Research and Development) merupakan metode penelitian yang digunakan untuk menghasilkan produk tertentu, dan menguji keefektifan produk tersebut. Penelitian pengembangan ini bertujuan untuk menghasilkan sebuah pedoman tes fisik atlet pencak silat kategori tanding. Menurut Borg \& Gall (2003, p.772) Research and Development adalah proses yang digunakan untuk mengembangkan dan memvalidasi produk-produk pendidikan baik produk yang berupa objek material seperti buku teks, CD pembelajaran maupun produk yang berupa proses dan prosedur yang ditemukan seperti metode mengajar atau metode mengorganisir pengajaran.

Subjek coba dalam penelitian dan pengembangan ini adalah sebagai berikut, untuk menguji skala kecil dilakukan terhadap UKM Tapak Suci UAD dan UKM Pencak Silat UGM. Sedangkan untuk menguji skala besar dilakukan terhadap PELATDA IPSI DIY, IPSI Kabupaten (Sleman, Bantul, dan Kota Jogja) DIY dan UKM Pencak silat (UNY, UGM, STTNAS, UIN dan UMY) DIY. Semua sampel yang digunakan dalam uji coba produk atlet pencak silat usia 17-35 tahun.

Teknik pengumpulan data juga merupakan faktor penting dalam penelitian, karena berhubungan langsung dengan data yang diperoleh. Teknik pengumpulan data dalam penelitian ini menggunakan angket dan tes pengukuran. Data yang dikumpulkan dalam penelitian ini adalah data dari hasil observasi, FGD (Focus Group Discussion), dan validasi ahli. Sedangkan pengembangan penelitian ini data diperoleh dari tes pengukuran masing-masing komponen kondisi fisik yang diperlukan dalam olahraga pencak silat.

Setelah FGD dilakukan kemudian uji validasi ahli untuk menentukan biomotor dan item tes apa saja yang diperlukan sesuai dengan karakteristik pencak silat kategori tanding. Setelah menemukan hasil dari validasi ahli 
tentang jenis biomotor dan tes apa saja yang dibutukan pencak silat kategori tanding, kemudian diujicobakan. Setelah diujicobakan hasil dari tes dan pengukuran masing-masing komponen fisik tersebut didistribusikan berdasarkan distribusi frekuensi digolongkan menjadi sangat baik, baik, sedang, kurang, dan sangat kurang.

Untuk perhitungannya dibutuhkan rerata dan simpangan baku. Penyusunan skor skala, mengubah angka kasar menjadi skor $\mathrm{T}$ dengan teknik rerata dan simpangan baku angka kasar. Penyusunan skor baku dengan rerata dan simpangan baku skor $\mathrm{T}$ yang digolongkan menjadi lima norma berdasar pada distribusi gejala normal, yaitu sangat baik, baik, sedang, kurang, sangat kurang. Data yang diperoleh tiap-tiap jenis tes merupakan data kasar dari hasil tiap tes yang di capai atlet. Selanjutnya hasil data kasar tersebut diubah menjadi nilai skor $\mathrm{T}$ dengan rumus sebagai berikut:

$\mathrm{T}=10\left(\frac{X-M}{S D}\right)+50$ (data reguler)

Keterangan:

$\mathrm{T}=$ nilai skor- $\mathrm{T}$

$\mathrm{M}=$ nilai rata-rata data kasar

$\mathrm{X}=$ nilai data kasar

$\mathrm{SD}=$ standar deviasi data kasar (Sujiono 2010, p.175), dan

$T_{i}=50+10\left(\frac{x_{i}-\bar{x}}{s}\right)($ data inversi $)$

Keterangan:

$T_{i}=$ nilai skor $-\mathrm{T}$

$x_{i}=$ nilai data kasar

$\bar{x}=$ nilai rata-rata data kasar

$\mathrm{s}=$ standar deviasi data kasar (Sudjana, 2005, p.104)

Setelah data sudah dirubah ke dalam $\mathrm{T}$ skor, kemudian data dimaknai, yaitu dengan mengkatagorikan data. Pengkatagorian dikelompokkan menjadi lima kategori yaitu sangat baik, baik, sedang, kurang, sangat kurang. Sedangkan pengakatagorian menggunakan acuan 5 batas norma, sebagai berikut:

Tabel 1. Rumus Pengkategorian Klasifikasi Norma untuk Tes (Power Lengan, Kekuatan Perut, Kekuatan Punggung, Power Tungkai, dan Daya Tahan Aerobik).

\begin{tabular}{cc}
\hline Rumus & Kategori \\
\hline $\mathrm{X}>\mathrm{M}+1,5 \mathrm{SD}$ & A atau Sangat Baik \\
$\mathrm{M}+0,5 \mathrm{SD} \leq \mathrm{X} \leq \mathrm{M}+1,5 \mathrm{SD}$ & $\mathrm{B}$ atau Baik \\
$\mathrm{M}-0,5 \mathrm{SD} \leq \mathrm{X}<\mathrm{M}+0,5 \mathrm{SD}$ & $\mathrm{C}$ atau Sedang \\
$\mathrm{M}-1,5 \mathrm{SD} \leq \mathrm{X}<\mathrm{M}-0,5 \mathrm{SD}$ & D atau Kurang \\
$\mathrm{X}<\mathrm{M}-1,5 \mathrm{SD}$ & E atau Sangat kurang \\
\hline
\end{tabular}

Karena di dalam penelitian ini ada beberapa tes fisik (fleksibilitas, kecepatan, kelincahan, dan daya tahan anaerobik) yang apabila nilai semakin sedikit semakin baik, maka rumus di atas dibalik menjadi.

Tabel 2. Rumus Pengkategorian Klasifikasi Norma untuk Tes (Fleksibilitas, Kecepatan,

Kelincahan, dan Daya Tahan Anaerobik)

\begin{tabular}{cc}
\hline Rumus & Kategori \\
\hline $\mathrm{X}<\mathrm{M}-1,5 \mathrm{SD}$ & A atau Sangat Baik \\
$\mathrm{M}-1,5 \mathrm{SD} \leq \mathrm{X}<\mathrm{M}-0,5 \mathrm{SD}$ & B atau Baik \\
$\mathrm{M}-0,5 \mathrm{SD} \leq \mathrm{X}<\mathrm{M}+0,5 \mathrm{SD}$ & C atau Sedang \\
$\mathrm{M}+0,5 \mathrm{SD} \leq \mathrm{X} \leq \mathrm{M}+1,5 \mathrm{SD}$ & $\mathrm{D}$ atau Kurang \\
$\mathrm{X}>\mathrm{M}+1,5 \mathrm{SD}$ & E atau Sangat kurang \\
\hline
\end{tabular}

Setelah norma dari setiap jenis tes diperoleh langkah selanjutnya adalah membuat rentang skor. Adapun cara pembuatan rentang skor menurut Ridho (2014, p.1) adalah :

Rumus Rentang Skala (RS) $=\mathrm{n}(\mathrm{m}-1) / \mathrm{m}$

Keterangan:

$\mathrm{n}=$ jumlah sampel

$\mathrm{m}=$ jumlah alternatif jawaban tiap item

Kemudian setelah rentang skor diperoleh, maka langkah berikutnya adalah menganalisis data untuk menarik kesimpulan dari penelitian yang dilakukan. Analisis data yang digunakan dari penelitian menggunakan teknik analisis deskriptif kuantitatif dengan persentase.

\section{HASIL DAN PEMBAHASAN}

Ada 26 macam jenis tes fisik yang sudah ada dan biasa digunakan oleh para pelatih pencak silat berikut dengan normanya. Masingmasing jenis tes dan norma yang sudah ada dan biasa diberikan kepada atlet saat ini masih secara umum untuk semua cabang olahraga. Jenis tes yang biasa diberikan kepada atlet juga masih parsial dan belum ada penyamaan jenis tes apa saja yang sesuai karakteristik pencak silat kategori tanding. Untuk itu, perlu adanya penyamaan persepsi tentang jenis tes fisik pencak silat dewasa kategori tanding.

Penentuan jenis tes yang sesuai dengan karakteristik pencak silat kategori tanding ini melalui beberapa tahapan. Adapun tahapantahapannya adalah sebagai berikut: Pertama, melakukan pemilihan jenis tes yang mendekati kebutuhan pencak silat kategori tanding dalam pertandingan. Kedua, Setelah hasil observasi didapat, tahapan selanjutnya adalah mengadakan FGD (Focus Group Discussion). Ketiga, Setelah hasil FGD didapat, tahapan selanjutnya adalah melakukan validasi kepada para ahli dan orang-orang berkopeten di bidangnya. Validasi 


\section{Jurnal Keolahragaan 4 (2), September 2016 - 148}

Cahniyo Wijaya Kuswanto

produk awal tes fisik dalam hal ini adalah ahli bidang tes pengukuran, ahli fisik, dan ahli media.

Pembuatan produk awal dalam penelitian ini berupa panduan tes fisik atlet pencak silat dewasa kategori tanding. Sebelum diujicobakan produk awal dalam skala kecil, harus dilakukan validasi kepada para ahli bidang media, ahli pencak silat, dan ahi tes pengukuran.

Validasi ahli dilakukan dengan cara menyampaikan draf produk awal tes fisik atlet pencak silat kategori tanding secara tertulis disertai dengan lembar evaluasi. Lembar evaluasi yang disampaikan berupa angket yang berisi jenis-jenis tes fisik atlet pencak silat kategori tanding dan saran serta komentar dari ahli terhadap panduan tes fisik yang telah disusun. Adapun hasil validasi masukan validator dalam tes fisik pencak silat kategori tanding ini dijabarkan sebagai berikut.

Pertama, ahli bidang media Masukan dan revisi yang diperoleh dari ahli media tentang produk draf awal ini adalah pertama, Urutan tes disesuaikan dengan urutan fisik sesuai kebutuhan energi ATP-Anaerobik-Aerobik. Kedua, Tes dirutkan dari yang ringan ke berat dari sisi sistem energi. Ketiga Setiap jenis tes dibuat norma sendiri-sendiri.

Kedua, ahli Pencak silat, masukan yang diberikan oleh ahli pencak silat. khususnya mengenai pelaksanaan tes untuk pencak silat yang pertama, bahasa disesuaikan dan diperbaiki agar mudah dipahami. Kedua, penjelasan pelaksanaan tentang tes harus detail. Ketiga, apabila tes dilakukan dalam satu rangkaian sebaiknya tes kelincahan tidak diletakkan setelah tes kecepatan. Keempat, pada buku panduan pelaksanaan tes sebaiknya diberikan keterangan tentang waktu recovery antar item tes.

Ketiga ahli pengukuran Revisi yang diberikan oleh ahli pengukuran mengenai tes pengukuran adalah yang pertama, pada tes side splite digunakan alat khusus, bukan hanya penggaris agar mencapai ketepatan ukur. Kedua, validitas, reliabilitas dan standar bisa di cari pembuktiannya bisa dengan refrensi yang sudah ada atau di cari sendiri.

Data hasil uji coba skala kecil kemudian dilakukan pengujian validitas instrumen tes menggunakan uji test-retest yaitu data hasil dua kali pengamatan menggunakan instrumen yang sama. Hasil pengujian validitas intrumen tes fisik atlet pencak silat dewasa kategori tanding meliputi fleksibilitas, kecepatan, power lengan, kekuatan perut, kekuatan punggung, power tungkai, kelincahan, daya tahan anaerobik, dan daya tahan anaerobik dapat dilihat Tabel 3.

Putra

Tabel 3. Hasil Uji Validitas Instrument Putra

\begin{tabular}{lccc}
\hline \multicolumn{1}{c}{ Instrumen Tes } & r hitung & r table & Ket \\
\hline Side splite & 0,847 & 0,344 & Valid \\
Sprint 40 meter & 0,973 & 0,344 & Valid \\
Push up 30 detik & 0,736 & 0,344 & Valid \\
Sit up 1 menit & 0,954 & 0,344 & Valid \\
Back up 1 menit & 0,989 & 0,344 & Valid \\
Standing triple jump & 0,812 & 0,344 & Valid \\
Shuttle run & 0,420 & 0,344 & Valid \\
Sprint 300 meter & 0,984 & 0,344 & Valid \\
Bleep test & 0,583 & 0,344 & Valid \\
\hline
\end{tabular}

Hasil pengujian hipotesis penelitian tersebut dibandingkan dengan nilai $r$ tabel. Nilai $r$ table, $\mathrm{N}=24$ taraf signifikansi 5\% sebesar 0,344 bedasarkan hasil tersebut diketahui bahwa uji validitas instrumen tes fisik menunjukkan $r$ hitung > $r$ tabel. Hasil ini dapat disimpulkan bahwa seluruh jenis tes fisik atlet pencak silat dewasa kategori tanding dinyatakan valid. Hasil pengujian reliabilitas instrumen tes fisik atlet pencak silat katagori tanding putra dapat dilihat pada Tabel 4.

Tabel 4. Hasil Uji Reliabilitas Putra

\begin{tabular}{lcc}
\hline \multicolumn{1}{c}{ Instrumen Tes } & $\begin{array}{c}\text { Koefisien } \\
\text { Alpha Cronbach }\end{array}$ & Ket \\
\hline Side splite & 0,917 & Reliabel \\
Sprint 40 meter & 0,986 & Reliabel \\
Push up 30 detik & 0,848 & Reliabel \\
Sit up 1 menit & 0,977 & Reliabel \\
Back up 1 menit & 0,995 & Reliabel \\
Standing triple jump & 0,896 & Reliabel \\
Shuttle run & 0,590 & Reliabel \\
Sprint 300 meter & 0,990 & Reliabel \\
Bleep test & 0,734 & Reliabel \\
\hline
\end{tabular}

Hasil pengujian reliabilitas keseluruhan instrumen tes fisik atlet pencak silat dewasa kategori tanding menunjukan koefisensi reliabilitas $>0,5$. Hasil ini dapat disimpulkan bahwasannya instrumen tes fisik atlet pencak silat dewasa kategori tanding adalah reliabel dan layak dilanjutkan untuk digunakan dalam pengambilan skala besar.

Putri

Hasil pengujian hipotesis penelitian tersebut dibandingkan dengan nilai $r$ tabel. Nilai $\mathrm{r}$ table, $\mathrm{N}=17$ taraf signifikansi 5\% sebesar 0,412 bedasarkan hasil tersebut diketahui bahwa uji validitas instrumen tes fisik menunjukkan $r$ hitung > $r$ tabel. Hasil ini dapat disimpul- 
kan bahwa seluruh jenis tes fisik atlet pencak silat dewasa kategori tanding dinyatakan valid.

Tabel 5. Hasil Uji Validitas Instrument Putri

\begin{tabular}{lccc}
\hline \multicolumn{1}{c}{ Instrumen Tes } & r hitung & r table & Ket \\
\hline Side splite & 0,753 & 0,412 & Valid \\
Sprint 40 meter & 0,918 & 0,412 & Valid \\
Push up 30 detik & 0,586 & 0,412 & Valid \\
Sit up 1 menit & 0,973 & 0,412 & Valid \\
Back up 1 menit & 0,598 & 0,412 & Valid \\
Standing triple jump & 0,864 & 0,412 & Valid \\
Shuttle run & 0,980 & 0,412 & Valid \\
Sprint 300 meter & 0,968 & 0,412 & Valid \\
Bleep test & 0,977 & 0,412 & Valid \\
\hline
\end{tabular}

Hasil pengujian reliabilitas instrumen tes fisik atlet pencak silat katagori tanding putri dapat dilihat pada Tabel 6 .

Tabel 6. Hasil Uji Reliabilitas Putri

\begin{tabular}{lcc}
\hline \multicolumn{1}{c}{ Instrumen Tes } & $\begin{array}{c}\text { Koefisien } \\
\text { Alpha Cronbach }\end{array}$ & Ket \\
\hline Side splite & 0,859 & Reliabel \\
Sprint 40 meter & 0,957 & Reliabel \\
Push up 30 detik & 0,739 & Reliabel \\
Sit up 1 menit & 0,986 & Reliabel \\
Back up 1 menit & 0,748 & Reliabel \\
Standing triple jump & 0,927 & Reliabel \\
Shuttle run & 0,990 & Reliabel \\
Sprint 300 meter & 0,984 & Reliabel \\
Bleep test & 0,988 & Reliabel \\
\hline
\end{tabular}

Hasil pengujian reliabilitas keseluruhan instrumen tes fisik atlet pencak silat dewasa kategori tanding menunjukan koefisensi reliabilitas >0,5. Hasil ini dapat disimpulkan bahwasanya instrumen tes fisik atlet pencak silat dewasa kategori tanding adalah reliabel dan layak dilanjutkan untuk digunakan dalam pengambilan skala besar.

Setelah pengujian skala kecil diperoleh hasil yang menyatakan bahwa seluruh instrumen tes dinyatakan valid dan reliabel, maka tahap selanjutnya adalah pengambilan data skala besar. Uji skala besar dalam penelitian ini dilakukan pada atlet, UKM PS UPN, UKM PS UIN Sunan Kalijaga, UKM PS UGM, UKM PS UNY, IPSI Kabupaten Sleman, IPSI Kota Yogyakarta, IPSI Kabupaten Bantul, dan PELATDA IPSI DIY. Pengambilan data skala besar ini menggunakan instrumen tes fisik atlet pencak silat dewasa kategori tanding yang sudah dinyatakan valid dan reliabel.

Hasil pengujian skala besar digunakan sebagai dasar untuk pembuatan standar nilai dan norma dalam tes fisik atlet pencak silat dewasa kategori tanding. Adapun formulasi rumus perhitungan pembuatan norma yang digunakan untuk untuk tes (kekuatan perut, kekuatan punggung, power lengan, power tungkai, dan daya tahan aerobik) pada Tabel 7.

Tabel 7. Rumus Pengkategorian Klasifikasi

Norma untuk Tes (Kekuatan Perut, Kekuatan Punggung, Power Lengan, Power Tungkai, dan Daya Tahan Aerobik).

\begin{tabular}{cc}
\hline Rumus & Kategori \\
\hline $\mathrm{X} \geq \mathrm{M}+1,5 \mathrm{SD}$ & A atau Sangat Baik \\
$\mathrm{M} \leq \mathrm{X}<\mathrm{M}+1,5 \mathrm{SD}$ & B atau Baik \\
$\mathrm{M}-1,5 \mathrm{SD} \leq \mathrm{X}<\mathrm{M}$ & $\mathrm{C}$ atau Sedang \\
$\mathrm{M}-1,5 \mathrm{SD} \geq \mathrm{X}$ & $\mathrm{D}$ atau Kurang \\
$\mathrm{X} \leq \mathrm{M}-1,5 \mathrm{SD}$ & E atau Sangat kurang \\
\hline
\end{tabular}

Adapun formulasi rumus perhitungan pembuatan norma yang digunakan untuk untuk tes (fleksibilitas, kecepatan, kelincahan, dan daya tahan anaerobik) adalah pada Tabel 8 .

Tabel 8. Rumus Pengkategorian Klasifikasi Norma untuk Tes (Fleksibilitas, Kecepatan,

Kelincahan, dan Daya Tahan Anaerobik).

\begin{tabular}{cc}
\hline Rumus & Kategori \\
\hline $\mathrm{X}<\mathrm{M}-1,5 \mathrm{SD}$ & A atau Sangat Baik \\
$\mathrm{M}-1,5 \mathrm{SD} \leq \mathrm{X}<\mathrm{M}-0,5 \mathrm{SD}$ & B atau Baik \\
$\mathrm{M}-0,5 \mathrm{SD} \leq \mathrm{X}<\mathrm{M}+0,5 \mathrm{SD}$ & C atau Sedang \\
$\mathrm{M}+0,5 \mathrm{SD} \leq \mathrm{X} \leq \mathrm{M}+1,5 \mathrm{SD}$ & $\mathrm{D}$ atau Kurang \\
$\mathrm{X}>\mathrm{M}+1,5 \mathrm{SD}$ & E atau Sangat kurang \\
\hline
\end{tabular}

Hasil data skala besar serta perhitungan norma dan standar penilaian tes fisik atlet pencak silat dewasa kategori tanding adalah sebagai berikut:

\section{Tes Fleksibilitas (Side Splite) $\mathrm{cm}$}

Putra

Hasil analisis data side splite di peroleh nilai rata-rata data kasar $(\bar{x}) 3.24$ dan standar deviasi kasar (s) 2.15. Kemudian data kasar dari side splite ini diubah ke dalam data inversi.

Sebagai contoh nilai data kasar $\left(x_{i}\right) 5$, nilai rata-rata data kasar $(\bar{x}) 3.24$, standar deviasi data kasar (s) 2.15. kemudian data ini di masukkan ke dalam rumus skor $\mathrm{T}=50+10 *(5-$ 3.24)/2.15= 41.80. Seluruh data kasar di ubah menjadi data inversi dengan menggunakan rumus $\mathrm{T}$ skor.

Setelah data inversi jadi, selanjutnya menentukan klasifikasi norma. Diperoleh hasil perhitungan norma dan standar tes side splite sebagai berikut: 
Tabel 9. Standar Nilai Side Splite Putra pada Tes Fisik Atlet Pencak Silat Dewasa Kategori Tading

\begin{tabular}{cc}
\hline Sangat Baik & $\mathrm{X}<0.01$ \\
Baik & $0.1 \leq \mathrm{X}<2.2$ \\
Sedang & $2.2 \leq \mathrm{X}<4.4$ \\
Kurang & $4.4 \leq \mathrm{X} \leq 6.4$ \\
Sangat Kurang & $\mathrm{X}>6.4$ \\
\hline
\end{tabular}

Putri

Hasil analisis data side splite di peroleh nilai rata-rata data $\operatorname{kasar}(\bar{x}) 2.34$ dan standar deviasi kasar (s) 1.55. Kemudian data kasar dari side splite ini diubah ke dalam data inversi.

Sebagai contoh nilai data kasar $\left(x_{i}\right) 4$, nilai rata-rata data $\operatorname{kasar}(\bar{x}) 2.34$ dan standar deviasi kasar (s) 1.55. kemudian data ini di masukkan ke dalam rumus skor $\mathrm{T}=50+10 *(4-$ $2.34) / 1.55=39.30$. Seluruh data kasar diubah menjadi data inversi dengan menggunakan rumus $\mathrm{T}$ skor.

Setelah data inversi jadi, selanjutnya menentukan klasifikasi norma. Diperoleh hasil perhitungan norma dan standar tes side splite sebagai berikut:

Tabel 10. Standar Nilai Side Splite Putri pada Tes Fisik Atlet Pencak Silat Dewasa Kategori Tading

\begin{tabular}{cc}
\hline Sangat Baik & $\mathrm{X}<0.01$ \\
Baik & $0.1 \leq \mathrm{X}<1.6$ \\
Sedang & $1.6 \leq \mathrm{X}<3.2$ \\
Kurang & $3.2 \leq \mathrm{X} \leq 4.6$ \\
Sangat Kurang & $\mathrm{X}>4.6$ \\
\hline
\end{tabular}

Tes Kecepatan (Sprint 40 Meter) Detik

Putra

Hasil analisis data sprint 40 meter di peroleh nilai rata-rata data $\operatorname{kasar}(\bar{x}) 5.87$ dan standar deviasi kasar (s) 0.52 . Kemudian data kasar dari sprint 40 meter ini diubah ke dalam data inversi.

Sebagai contoh nilai data kasar $\left(x_{i}\right) 5.69$, nilai rata-rata data $\operatorname{kasar}(\bar{x}) 5.87$ dan standar deviasi kasar (s) 0.52. kemudian data ini di masukkan ke dalam rumus skor $\mathrm{T}=$ $50+10 *(5.69-5.87) / 0.52=53.37$. Seluruh data kasar di ubah menjadi data inversi dengan menggunakan rumus $\mathrm{T}$ skor.

Setelah data inversi jadi, selanjutnya menentukan klasifikasi norma. Diperoleh hasil perhitungan norma dan standar tes sprint 40 meter sebagai berikut:
Tabel 11. Standar Nilai Sprint 40 Meter Putra pada Tes Fisik Atlet Pencak Silat Dewasa Kategori Tading

\begin{tabular}{cc}
\hline Sangat Baik & $\mathrm{X}<5.08$ \\
Baik & $5.08 \leq \mathrm{X}<5.61$ \\
Sedang & $5.61 \leq \mathrm{X}<6.14$ \\
Kurang & $6.14 \leq \mathrm{X} \leq 6.65$ \\
Sangat Kurang & $\mathrm{X}>6.65$ \\
\hline
\end{tabular}

Putri

Hasil analisis data sprint 40 meter di peroleh nilai rata-rata data kasar $(\bar{x}) 6.98$ dan standar deviasi kasar (s) 0.70. Kemudian data kasar dari sprint 40 meter ini diubah ke dalam data inversi.

Sebagai contoh nilai data kasar $\left(x_{i}\right) 7.11$, nilai rata-rata data kasar $(\bar{x}) 6.98$ dan standar deviasi kasar (s) 0.70. kemudian data ini di masukkan kedalam rumus skor $\mathrm{T}=10+50 *(7.11$ $6.98) / 0.70=48.15$. Seluruh data kasar diubah menjadi data inversi dengan menggunakan rumus $\mathrm{T}$ skor.

Setelah data inversi jadi, selanjutnya menentukan klasifikasi norma. Diperoleh hasil perhitungan norma dan standar tes sprint 40 meter sebagai berikut:

Tabel 12. Standar Nilai Sprint 40 Meter Putri pada Tes Fisik Atlet Pencak Silat Dewasa Kategori Tading

\begin{tabular}{cc}
\hline Sangat Baik & X $<5.94$ \\
Baik & $5.94 \leq$ X M 6.64 \\
Sedang & $6.64 \leq$ X $<$ M 7.34 \\
Kurang & $7.34 \leq X \leq$ M 8.02 \\
Sangat Kurang & X $>8.02$ \\
\hline
\end{tabular}

\section{Tes Power Lengan (Push Up 30 Detik) Kali}

Putra

Hasil analisis data push up 30 detik di peroleh nilai rata-rata data $\operatorname{kasar}(\bar{x}) 40.10$ dan standar deviasi kasar (s) 8.62. Kemudian data kasar dari push up 30 detik ini diubah ke dalam data inversi.

Sebagai contoh nilai data kasar $\left(x_{i}\right) 39$, nilai rata-rata data kasar $(\bar{x}) 40.10$ dan standar deviasi kasar (s) 8.62. kemudian data ini di masukkan kedalam rumus skor $\mathrm{T}=50+10 *(39$ 40.10)/8.62 $=48.72$. Seluruh data kasar diubah menjadi data inversi dengan menggunakan rumus $\mathrm{T}$ skor.

Setelah data inversi jadi, selanjutnya menentukan klasifikasi norma. Diperoleh hasil perhitungan norma dan standar tes push up 30 detik sebagai berikut: 


\section{Jurnal Keolahragaan 4 (2), September 2016 - 151}

Cahniyo Wijaya Kuswanto

Tabel 13. Standar Nilai Push Up 30 Detik Putra pada Tes Fisik Atlet Pencak Silat Dewasa Kategori Tading

\begin{tabular}{cc}
\hline Sangat Baik & $X>53$ \\
Baik & $45 \leq X \leq 53$ \\
Sedang & $37 \leq X<45$ \\
Kurang & $27 \leq X<37$ \\
Sangat Kurang & $X<27$ \\
\hline
\end{tabular}

Putri

Hasil analisis data push up 30 detik di peroleh nilai rata-rata data $\operatorname{kasar}(\bar{x}) 28.96$ dan standar deviasi kasar (s) 6.41. Kemudian data kasar dari push up 30 detik ini diubah ke dalam data inversi.

Sebagai contoh nilai data kasar $\left(x_{i}\right) 33$, nilai rata-rata data kasar $(\bar{x}) 28.96$ dan standar deviasi kasar (s) 6.41. kemudian data ini di masukkan ke dalam rumus skor $T_{i}=50+10 *(33$ 28.96)/6.41= 56.30. Seluruh data kasar diubah menjadi data inversi dengan menggunakan rumus $\mathrm{T}$ skor.

Setelah data inversi jadi, selanjutnya menentukan klasifikasi norma. Diperoleh hasil perhitungan norma dan standar tes push up 30 detik sebagai berikut:

Tabel 14. Standar Nilai Push Up 30 Detik Putri pada Tes Fisik Atlet Pencak Silat Dewasa Kategori Tading

\begin{tabular}{cc}
\hline Sangat Baik & $\mathrm{X}>39$ \\
Baik & $33 \leq \mathrm{X} \leq 39$ \\
Sedang & $27 \leq \mathrm{X}<33$ \\
Kurang & $19 \leq \mathrm{X}<27$ \\
Sangat Kurang & $\mathrm{X}<19$ \\
\hline
\end{tabular}

\section{Tes Kekuatan Perut (sit up 1 menit) kali}

Putra

Hasil analisis data sit up 1 menit di peroleh nilai rata-rata data $\operatorname{kasar}(\bar{x}) 62.97$ dan standar deviasi kasar (s) 15.23. Kemudian data kasar dari sit up 1 menit ini diubah ke dalam data inversi.

Sebagai contoh nilai data kasar $\left(x_{i}\right) 50$, nilai rata-rata data kasar $(\bar{x}) 62.97$ dan standar deviasi kasar (s) 15.23. kemudian data ini di masukkan ke dalam rumus skor $T_{i}=50+10 *(50-$ $62.97) / 15.23=41.48$. Seluruh data kasar di ubah menjadi data inversi dengan menggunakan rumus $\mathrm{T}$ skor.

Setelah data inversi jadi, selanjutnya menentukan klasifikasi norma. Diperoleh hasil perhitungan norma dan standar tes sit up 1 menit sebagai berikut:
Tabel 15. Standar Nilai Sit Up 1 Menit Putra pada Tes Fisik Atlet Pencak Silat Dewasa

Kategori Tading

\begin{tabular}{cc}
\hline Sangat Baik & $\mathrm{X}>86$ \\
Baik & $72 \leq \mathrm{X} \leq 86$ \\
Sedang & $56 \leq \mathrm{X}<72$ \\
Kurang & $40 \leq \mathrm{X}<56$ \\
Sangat Kurang & $\mathrm{X}<40$ \\
\hline
\end{tabular}

Putri

Hasil analisis data sit up 1 menit di peroleh nilai rata-rata data $\operatorname{kasar}(\bar{x}) 55.62$ dan standar deviasi kasar (s) 14.19. Kemudian data kasar dari sit up 1 menit ini diubah ke dalam data inversi.

Sebagai contoh nilai data kasar $\left(x_{i}\right) 49$, nilai rata-rata data $\operatorname{kasar}(\bar{x}) 55.62$ dan standar deviasi kasar (s) 14.19. Kemudian data ini di masukkan ke dalam rumus skor $T_{i}=50+10 *(49$ $55.62) / 14.19=45.34$. Seluruh data kasar di ubah menjadi data inversi dengan menggunakan rumus $\mathrm{T}$ skor.

Setelah data inversi jadi, selanjutnya menentukan klasifikasi norma. Diperoleh hasil perhitungan norma dan standar tes sit up 1 menit sebagai berikut:

Tabel 16. Standar Nilai Sit Up 1 Menit Putri pada Tes Fisik Atlet Pencak Silat Dewasa Kategori Tading

\begin{tabular}{cc}
\hline Sangat Baik & $X>77$ \\
Baik & $64 \leq X \leq 77$ \\
Sedang & $50 \leq X<64$ \\
Kurang & $34 \leq X<50$ \\
Sangat Kurang & $X<34$ \\
\hline
\end{tabular}

\section{Tes Kekuatan Punggung (back up 1 menit)} kali

Putra

Hasil analisis data back up 1 menit di peroleh nilai rata-rata data $\operatorname{kasar}(\bar{x}) 95.84$ dan standar deviasi kasar (s) 19.15. Kemudian data kasar dari back up 1 menit ini diubah ke dalam data inversi dengan rumus:

Sebagai contoh nilai data kasar $\left(x_{i}\right) 115$, nilai rata-rata data $\operatorname{kasar}(\bar{x}) 95.84$ dan standar deviasi kasar (s) 19.15. Kemudian data ini di masukkan ke dalam rumus skor $T_{i}=$ $50+10 *(115-95.84) / 19.15=60.01$. Seluruh data kasar diubah menjadi data inversi dengan menggunakan rumus $\mathrm{T}$ skor.

Setelah data inversi jadi, selanjutnya menentukan klasifikasi norma. Diperoleh hasil perhitungan norma dan standar tes back up 1 menit sebagai berikut: 
Tabel 17. Standar Nilai Back Up 1 Menit Putra pada Tes Fisik Atlet Pencak Silat Dewasa Kategori Tading

\begin{tabular}{cc}
\hline Sangat Baik & $X>125$ \\
Baik & $106 \leq X \leq 125$ \\
Sedang & $87 \leq X<106$ \\
Kurang & $67 \leq X<87$ \\
Sangat Kurang & $X<67$ \\
\hline
\end{tabular}

Putri

Hasil analisis data back up 1 menit di peroleh nilai rata-rata data kasar $(\bar{x}) 84.24$ dan standar deviasi kasar (s) 14.57. Kemudian data kasar dari back up 1 menit ini diubah ke dalam data inversi.

Sebagai contoh nilai data kasar $\left(x_{i}\right) 74$, nilai rata-rata data $\operatorname{kasar}(\bar{x}) 84.24$ dan standar deviasi kasar (s) 14.57. Kemudian data ini di masukkan ke dalam rumus skor $T_{i}=50+10 *(74-$ $84.24) / 14.57=42.97$. Seluruh data kasar di ubah menjadi data inversi dengan menggunakan rumus $\mathrm{T}$ skor.

Setelah data inversi jadi, selanjutnya menentukan klasifikasi norma. Diperoleh hasil perhitungan norma dan standar tes back up 1 menit sebagai berikut:

Tabel 18. Standar Nilai Back Up 1 Menit Putri pada Tes Fisik Atlet Pencak Silat Dewasa Kategori Tading

\begin{tabular}{cc|}
\hline Sangat Baik & $X>106$ \\
Baik & $93 \leq X \leq 106$ \\
Sedang & $78 \leq X<93$ \\
Kurang & $62 \leq X<78$ \\
Sangat Kurang & $X<62$ \\
\hline
\end{tabular}

\section{Tes Power Tungkai (Standing Triple Jump)} Meter

Putra

Hasil analisis data standing triple jump di peroleh nilai rata-rata data $\operatorname{kasar}(\bar{x}) 6.44$ dan standar deviasi kasar (s) 0.60. Kemudian data kasar dari standing triple jump ini diubah ke dalam data inversi.

Sebagai contoh nilai data kasar $\left(x_{i}\right) 5.61$, nilai rata-rata data kasar $(\bar{x}) 6.44$ dan standar deviasi kasar (s) 0.60. Kemudian data ini di masukkan ke dalam rumus skor $T_{i}=$ $50+10 *(5.61-6.44) / 0.60=51.17$. Seluruh data kasar diubah menjadi data inversi dengan menggunakan rumus $\mathrm{T}$ skor.

Setelah data inversi jadi, selanjutnya menentukan klasifikasi norma. Diperoleh hasil perhitungan norma dan standar tes standing triple jump sebagai berikut:
Tabel 19. Standar nilai Standing Triple Jump Putra pada Tes Fisik Atlet Pencak Silat Dewasa Kategori Tading

\begin{tabular}{cc}
\hline Sangat Baik & $X>7.34$ \\
Baik & $6.75 \leq X \leq 7.34$ \\
Sedang & $6.15 \leq X<6.75$ \\
Kurang & $5.54 \leq X<6.15$ \\
Sangat Kurang & $X<5.54$ \\
\hline
\end{tabular}

Putri

Hasil analisis data standing triple jump di peroleh nilai rata-rata data kasar $(\bar{x}) 5.32$ dan standar deviasi kasar (s) 0.46. Kemudian data kasar dari standing triple jump ini diubah ke dalam data inversi.

Sebagai contoh nilai data kasar $\left(x_{i}\right) 5.80$, nilai rata-rata data kasar $(\bar{x}) 5.32$ dan standar deviasi kasar (s) 0.46. Kemudian data ini di masukkan ke dalam rumus skor $T_{i}=$ $50+10 *(5.80-5.32) / 0.46=60.63$. Seluruh data kasar di ubah menjadi data inversi dengan menggunakan rumus $\mathrm{T}$ skor.

Setelah data inversi jadi, selanjutnya menentukan klasifikasi norma. Diperoleh hasil perhitungan norma dan standar tes standing triple jump sebagai berikut:

Tabel 20. Standar Nilai Standing Triple Jump Putri pada Tes Fisik Atlet Pencak Silat Dewasa Kategori Tading

\begin{tabular}{cc}
\hline Sangat Baik & $\mathrm{X}>6.00$ \\
Baik & $5.55 \leq \mathrm{X} \leq 6.00$ \\
Sedang & $5.10 \leq \mathrm{X}<5.55$ \\
Kurang & $4.63 \leq \mathrm{X}<5.10$ \\
Sangat Kurang & $\mathrm{X}<4.63$ \\
\hline
\end{tabular}

\section{Tes Kelincahan (Shuttle Run) Detik}

Putra

Hasil analisis data shuttle run di peroleh nilai rata-rata data kasar $(\bar{x}) 11.01$ dan standar deviasi kasar (s) 1.01. Kemudian data kasar dari shuttle run ini diubah ke dalam data inversi.

Sebagai contoh nilai data kasar $\left(x_{i}\right)$ 10.17, nilai rata-rata data kasar $(\bar{x}) 11.01$ dan standar deviasi kasar (s) 1.01, kemudian data ini di masukkan ke dalam rumus skor $T_{i}=$ $50+10 *(11.01-10.17) / 1.01=58.37$. Seluruh data kasar diubah menjadi data inversi dengan menggunakan rumus $\mathrm{T}$ skor.

Setelah data inversi jadi, selanjutnya menentukan klasifikasi norma. Diperoleh hasil perhitungan norma dan standar tes shuttle run sebagai berikut: 


\section{Jurnal Keolahragaan 4 (2), September 2016 - 153}

Cahniyo Wijaya Kuswanto

Tabel 21. Standar Nilai Shuttle Run Putra pada Tes Fisik Atlet Pencak Silat Dewasa Kategori Tading

\begin{tabular}{cc}
\hline Sangat Baik & $\mathrm{X}<9.50$ \\
Baik & $9.50 \leq \mathrm{X}<10.52$ \\
Sedang & $10.52 \leq \mathrm{X}<11.53$ \\
Kurang & $11.53 \leq \mathrm{X} \leq 12.53$ \\
Sangat Kurang & $\mathrm{X}>12.53$ \\
\hline
\end{tabular}

Putri

Hasil analisis data shuttle run di peroleh nilai rata-rata data kasar $(\bar{x}) 11.96$ dan standar deviasi kasar (s) 0.81. Kemudian data kasar dari shuttle run ini diubah ke dalam data inversi.

Sebagai contoh nilai data kasar $\left(x_{i}\right)$ 12.06, nilai rata-rata data $\operatorname{kasar}(\bar{x}) 11.96$ dan standar deviasi kasar (s) 0.81 , kemudian data ini di masukkan ke dalam rumus skor $T_{i}=$ $50+10 *(12.06-11.96) / 0.81=48.78$. Seluruh data kasar di ubah menjadi data inversi dengan menggunakan rumus $\mathrm{T}$ skor.

Setelah data inversi jadi, selanjutnya menentukan klasifikasi norma. Diperoleh hasil perhitungan norma dan standar tes shuttle run sebagai berikut:

Tabel 22. Standar Nilai Shuttle Run Putri pada Tes Fisik Atlet Pencak Silat Dewasa Kategori Tading

\begin{tabular}{cc}
\hline Sangat Baik & $\mathrm{X}<10.75$ \\
Baik & $10.75 \leq \mathrm{X}<11.57$ \\
Sedang & $11.57 \leq \mathrm{X}<12.38$ \\
Kurang & $12.38 \leq \mathrm{X} \leq 13.17$ \\
Sangat Kurang & $>13.17$ \\
\hline
\end{tabular}

Tes Daya Tahan Anaerobik (Sprint 300 Meter) Detik

Putra

Hasil analisis data sprint 300 meter di peroleh nilai rata-rata data kasar $(\bar{x}) 53.83$ dan standar deviasi kasar (s) 7.25. Kemudian data kasar dari sprint 300 meter ini diubah ke dalam data inversi.

Sebagai contoh nilai data kasar $\left(x_{i}\right)$ 52.39 , nilai rata-rata data kasar $(\bar{x}) 53.83$ dan standar deviasi kasar (s) 7.25, kemudian data ini di masukkan ke dalam rumus skor $T_{i}=$ $50+10 *(53.83-52.39) / 7.25=51.99$. Seluruh data kasar di ubah menjadi data inversi dengan menggunakan rumus $\mathrm{T}$ skor.

Setelah data inversi jadi, selanjutnya menentukan klasifikasi norma. Diperoleh hasil perhitungan norma dan standar tes sprint 300 meter sebagai berikut:
Tabel 23. Standar Nilai Sprint 300 Meter Putra pada Tes Fisik Atlet Pencak Silat Dewasa Kategori Tading

\begin{tabular}{cc}
\hline Sangat Baik & $\mathrm{X}<42.95$ \\
Baik & $42.95 \leq \mathrm{X}<50.22$ \\
Sedang & $50.22 \leq \mathrm{X}<57.47$ \\
Kurang & $57.47 \leq \mathrm{X} \leq 1.04 .71$ \\
Sangat Kurang & $\mathrm{X}>1.04 .71$ \\
\hline
\end{tabular}

Putri

Hasil analisis data sprint 300 meter di peroleh nilai rata-rata data $\operatorname{kasar}(\bar{x}) 71.18$ dan standar deviasi kasar (s) 11.59. Kemudian data kasar dari sprint 300 meter ini diubah ke dalam data inversi dengan rumus:

Sebagai contoh nilai data kasar $\left(x_{i}\right)$ 75.33 , nilai rata-rata data $\operatorname{kasar}(\bar{x}) 71.18$ dan standar deviasi kasar (s) 11.59, kemudian data ini di masukkan ke dalam rumus skor $T_{i}=$ $50+10 *(75.33-71.18) / 11.59=46.42$. Seluruh data kasar di ubah menjadi data inversi dengan menggunakan rumus $\mathrm{T}$ skor.

Setelah data inversi jadi, selanjutnya menentukan klasifikasi norma. Diperoleh hasil perhitungan norma dan standar tes sprint 300 meter sebagai berikut:

Tabel 24. Standar Nilai Sprint 300 Meter Putri pada Tes Fisik Atlet Pencak Silat Dewasa Kategori Tading

\begin{tabular}{cc}
\hline Sangat Baik & $\mathrm{X}<53.80$ \\
Baik & $53.80 \leq \mathrm{X}<01.05 .40$ \\
Sedang & $01.05 .40 \leq \mathrm{X}<01.16 .98$ \\
Kurang & $01.16 .98 \leq \mathrm{X} \leq 01.28 .56$ \\
Sangat Kurang & $\mathrm{X}>01.28 .56$ \\
\hline
\end{tabular}

Tes Daya Tahan Aerobik (Bleep Test) Level

Putra

Hasil analisis data bleep test di peroleh nilai rata-rata data kasar $(\bar{x}) 11.2$ dan standar deviasi kasar (s) 9.2. Kemudian data kasar dari bleep test ini diubah ke dalam data inversi.

Sebagai contoh nilai data kasar $\left(x_{i}\right) 7.8$, nilai rata-rata data $\operatorname{kasar}(\bar{x}) 11.2$ dan standar deviasi kasar (s) 9.2, kemudian data ini di masukkan ke dalam rumus skor $T_{i}=$ $50+10 *(7.8-11.2) / 9.2=54.39$. Seluruh data kasar diubah menjadi data inversi dengan menggunakan rumus T skor.

Setelah data inversi jadi, selanjutnya menentukan klasifikasi norma. Diperoleh hasil perhitungan norma dan standar tes bleep test sebagai berikut: 


\section{Jurnal Keolahragaan 4 (2), September 2016 - 154}

Cahniyo Wijaya Kuswanto

Tabel 25. Standar Nilai Bleep Test Putra pada Tes Fisik Atlet Pencak Silat Dewasa Kategori Tading

\begin{tabular}{cc}
\hline Sangat Baik & $\mathrm{X}>11 / 1$ \\
Baik & $9 / 4 \leq \mathrm{X} \leq 11 / 1$ \\
Sedang & $7 / 7 \leq \mathrm{X}<9 / 4$ \\
Kurang & $5 / 8 \leq \mathrm{X}<7 / 7$ \\
Sangat Kurang & $\mathrm{X}<5 / 8$ \\
\hline
\end{tabular}

Penjelasan: untuk Bleep Test setelah tanda (/) merupakan penjelasan dari repetisi level sebelumnya. Sebagai contoh jika 9/4 artinya level 9 repetisi ke 4.

Putri

Hasil analisis data bleep test di peroleh nilai rata-rata data kasar $(\bar{x}) 5.92$ dan standar deviasi kasar (s) 1.52. Kemudian data kasar dari bleep test ini diubah ke dalam data inversi.

Sebagai contoh nilai data kasar $\left(x_{i}\right) 7.4$, nilai rata-rata data kasar $(\bar{x}) 5.92$ dan standar deviasi kasar (s) 1.52, kemudian data ini di masukkan ke dalam rumus skor $T_{i}=$ $50+10 *(7.4-5.92) / 1.52=59.74$. Seluruh data kasar diubah menjadi data inversi dengan menggunakan rumus $\mathrm{T}$ skor.

Setelah data inversi jadi, selanjutnya menentukan klasifikasi norma. Diperoleh hasil perhitungan norma dan standar tes bleep test sebagai berikut:

Tabel 26. Standar Nilai Bleep Test Putri pada Tes Fisik Atlet Pencak Silat Dewasa Kategori Tading

\begin{tabular}{cc}
\hline Sangat Baik & $\mathrm{X}>8 / 2$ \\
Baik & $6 / 8 \leq \mathrm{X} \leq 8 / 2$ \\
Sedang & $5 / 3 \leq \mathrm{X}<6 / 7$ \\
Kurang & $3 / 6 \leq \mathrm{X}<5 / 2$ \\
Sangat Kurang & $\mathrm{X}<3 / 6$
\end{tabular}

Penjelasan: untuk Bleep Test setelah tanda (/) merupakan penjelasan dari repetisi level sebelumnya. Sebagai contoh jika 6/8 artinya level 6 repetisi ke 8 .

\section{SIMPULAN}

Berdasarkan penelitian yang dilakukan, maka ditarik kesimpulan sebagai berikut: Pertama, berdasarkan hasil observasi dan FGD (Focus Group Discussion) yang dihadiri oleh para pelatih pencak silat, ahli materi pencak silat dan ahli kondisi fisik, dihasilkan bahwa biomotor yang diberikan saat tes fisik pada atlet pencak silat dewasa kategori tanding adalah fleksibilitas, kecepatan, kelincahan, power lengan, kekuatan perut, kekuatan punggung, power tungkai, daya tahan anaerobik, dan daya tahan aerobik.

Kedua, jenis tes fisik pencak silat dewasa kategori tanding antara lain adalah fleksibilitas (side splite), kecepatan (sprint 40 meter), kelincahan (shuttle run), power lengan (push up 30 detik ), kekuatan perut (sit up), kekuatan punggung (back up), power tungkai (standing triple jump), daya tahan anaerobik (lari 300 meter), dan daya tahan aerobik (bleep tes).

Ketiga, hasil uji validasi pada seluruh jenis tes menunjukkan bahwa $r$ hitung $>r$ table. Hasil tersebut menunjukan bahwa seluruh jenis tes yang disusuna dalam tes fisik pencak silat dewasa kategori tanding dinyatakan valid. Hasil pengujian reliabilitas pada seluruh jenis tes fisik pencak silat dewasa kategori tanding menunjukkan koefisien reliabilitas putra dan putri $>0,5$ hasil ini dapat disimpulkan bahwa seluruh jenis tes fisik pencak silat dewasa kategori tanding adalah reliabel.

\section{DAFTAR PUSTAKA}

Sujiono, A. (2010). Pengantar statistika pendidikan. Jakarta: Raja Grafindo Perkasa.

Iswana, B., \& Siswantoyo, S. (2013). Model latihan keterampilan gerak pencak silat anak usia 9-12 tahun.Jurnal Keolahragaan, $\quad 1(1), 26-36$. doi:http://dx.doi.org/10.21831/jk.v1i1.2 343

Borg, W. R., \& Gall, R, (2003). Education research: An introduction $\left(5^{\text {Th }}\right.$ ed). New York: Longman.

Ridho, M.R. (2014). Cara membuat rentang skala untuk analisis deskriptif. Diambil pada tanggal 20 mei 2015 dari www.emerer.com.

Sudjana. (2005).Metoda statistika. Bandung: Tarsito. 